\title{
Göz Ardı Edilen Program ve Türkiye'deki Yansımaları
}

\author{
Ali Orhan ${ }^{1}$, Filiz Evran Acar ${ }^{2}$ \\ ${ }^{1}$ Yabancı Diller Yüksekokulu, Bülent Ecevit Üniversitesi, Zonguldak, Türkiye \\ ${ }^{2}$ Eğitim Programlarl ve Öğretim Anabilim Dalı, Eğitim Fakültesi, Düzce Üniversitesi, Düzce, Türkiye
}

Sorumlu Yazar: Ali Orhan, ali_orh_an@hotmail.com

Makale Türü: Derleme Makalesi

Kaynak Gösterimi: Orhan, A., \& Acar, F. E. (2018). Göz ardı edilen program ve Türkiye'deki yansımaları. Eğitimde Kuram ve Uygulama, 14(3), 292-305. doi:10.17244/eku.375778

\section{Null Curriculum and Its Reflections in Turkey}

\author{
Ali Orhan ${ }^{1}$, Filiz Evran Acar ${ }^{2}$ \\ ${ }^{1}$ School of Foreign Languages, Bülent Ecevit University, Zonguldak, Turkey \\ ${ }^{2}$ Department of Curriculum and Instruction, Faculty of Education, Düzce University, Düzce, Turkey
}

Corresponding Author: Ali Orhan, ali_orh_an@hotmail.com

Article Type: Review Article

To Cite This Article: Orhan, A., \& Acar, F. E. (2018). Göz ardı edilen program ve Türkiye’deki yansımaları. Ĕ̌itimde Kuram ve Uygulama, 14(3), 292-305. doi:10.17244/eku.375778 


\title{
Göz Ardı Edilen Program ve Türkiye'deki Yansımaları
}

\author{
Ali Orhan ${ }^{1}$, Filiz Evran Acar ${ }^{2}$ \\ ${ }^{1}$ Yabancı Diller Yüksekokulu, Bülent Ecevit Üniversitesi, Zonguldak, Türkiye \\ ORCID: http://orcid.org/0000-0003-1234-3919 \\ ${ }^{2}$ Eğitim Programlarl ve Öğretim Anabilim Dall, Ĕ̌itim Fakültesi, Düzce Üniversitesi, Düzce, Türkiye \\ ORCID: http://orcid.org/0000-0002-0453-8508
}

\begin{tabular}{|c|c|}
\hline$\ddot{O} z$ & Makale Bilgisi \\
\hline 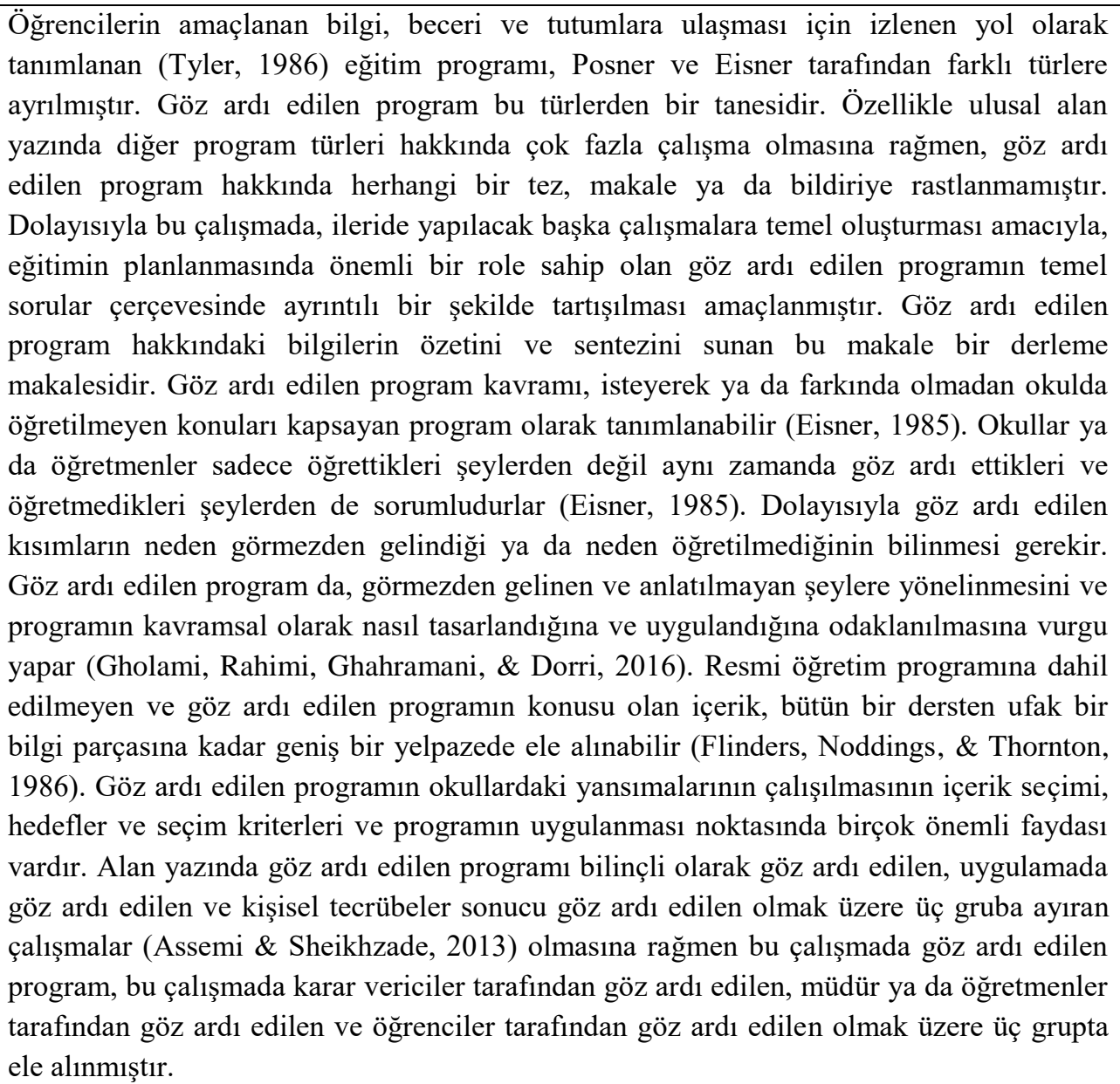 & $\begin{array}{l}\text { Anahtar Kelimeler: Göz ard1 } \\
\text { edilen program, Öğretim } \\
\text { programı inceleme, Öğretim } \\
\text { programı türleri, Derleme } \\
\text { Makale Geçmişi: } \\
\text { Geliş: } 06 \text { Ocak } 2018 \\
\text { Düzeltme: } 26 \text { Ocak } 2018 \\
\text { Kabul: } 16 \text { Şubat } 2018\end{array}$ \\
\hline
\end{tabular}




\section{Null Curriculum and Its Reflections in Turkey}

Abstract
Curriculum, which can be defined as the path that is followed to acquire intented
knowledge, ability and attitude, is divided into different types by Posner (1995) and Eisner
(1985). Null curriculum ${ }^{1}$ is one of these types. Although there are many studies about
other curriculum types, no study about null curriculum are seen in literature in Turkey. So
in this study, it is aimed to discuss the null curriculum elaborately, which has important
role on planning education, within the frame of some questions to provide a basis for
future studies. This study, which provides summary and synthesis of the knowledge about
null curriculum that was found, is literature review. Null curriculum term can be described
as the curriculum which includes what is not taught in schools either intentionally or
unintentionally (Eisner, 1985). Schools or teachers are responsible for not only what they
teach but also what they neglect to teach (Eisner, 1985). So the reasons, which cause to
neglect or not to teach these parts, should be found out and understood. Null curriculum
points out to the analysis of what is left out or neglected, and concentrates on how the
curriculum is designed and implemented (Gholami, Rahimi, Ghahramani, \& Dorri, 2016).
The content, which are left out from the formal curriculum and included in the null
curriculum, can be anything from the whole lesson to little information (Flinders,
Noddings, \& Thornton, 1986). Studying the reflections of null curriculum in schools has
many benefits for deciding on content, aims and their choosing criteria and
implementation of curriculum. Although null curriculum is divided into three types as
intented, implemented and experiential (Assemi \& Sheikhzade, 2013) in literature, in this
study it is discussed in three types as the curriculum which is neglected by decision
makers, by headmasters and teachers and by students.

Article Info

Keywords: Null curriculum, Curriculum review, Curriculum types, Literature review

\section{Article History:}

Received: 06 January 2018

Revised: 26 January 2018

Accepted: 16 February 2018

Article Type: Review Article

\footnotetext{
${ }^{1}$ Orijinalim "null curriculum" olan terim Türkçe'de öğretisiz öğretim programı, umursanmayan öğretim programı ve görmezden gelinen öğretim programı gibi terimlerle de anılmaktadır. Ancak bu çalışmada bahsedilen terim yerine göz ardı edilen program kavramı kullanılmıştır.
} 


\section{Giriş}

Tarihi M.Ö. birinci yüzyıla kadar uzanan (Demirel, 2013) eğitim programı kavramı eğitim alanında "izlenen yol” anlamına gelmektedir (Olivia, 1988). Julius Ceaser döneminde atların üzerinde koştuğu oval biçimindeki koşu pisti anlamına gelen "curriculum" kavramı bugün eğitim alanında daha soyut bir anlamda kullanılmaya başlanmıştır (Demirel, 2013). Günümüzde "curriculum" kelimesinin kökeninden hareketle birçok eğitimci ve yazar kelimeyi Türkçeye "izlence" ya da "yetişek" olarak çevirmişlerdir. Ancak günümüzde kelimenin en yaygın kullanılan karş1lı̆̆ "eğitim programı" kavramıdır. Yukarıda etimolojik anlamda kökenlerine değinilen eğitim programı kavramı 20. yüzyıla kadar basit bir şekilde sadece konular listesi, ders içerikleri, derslerin siralanması ve öğretim materyalleri listesi gibi anlamlarda kullanılmaktaydı (Demirel, 2013). Bu yıllardan sonra eğitim programı kavramı farklı eğitim uzmanları ve program geliştirmeciler tarafından tanımlanmaya çalışılmıştır. Dolayısıyla farklı yıllarda farklı tanımlamalar ortaya çıkmıştır. Caswell ve Campbell (1935) eğitim programını basit anlamda sadece bir konular listesi olarak değil, aksine öğrencilerin öğretmenlerin gözetiminde kazandığı tüm yaşantılar olarak tanımlamaktadır. Neagley ve Evans'a (1967) göre ise eğitim programı öğrencilerin becerilerinin geliştirilmesi için hedeflenen öğrenme çıktılarına ulaşmalarında onlara yardım etmek için okulun sunduğu planlı tüm yaşantılardır. Good (1973) ise eğitim programını bir alanda diploma ya da sertifika alabilmek için tamamlanması gereken ders ya da konuların sistematik bir şekilde sıralanmasıyla oluşan liste olarak tanımlamıştır. Tanner ve Tanner'e (1980) göre ise eğitim programı, okul veya üniversitenin sorumluluğu altında planlı bir şekilde kazandırılan bilgi ve yaşantıların yeniden yapılandırılmasıdır. Saylor, Alexander ve Lewis (1981) ve Taba (1962) da benzer bir şekilde eğitim programını eğitilmesi düşünülen bireylere, hedeflere ulaşmak için öğrenme yaşantılarını kazandırma planı olarak tanımlarlar. Tyler (1986) ise eğitim programını öğrencilerin amaçlanan bilgi, beceri ve tutumlara ulaşması için izlenen yol olarak tanımlar. Doll'a (1986) göre ise eğitim programı, okul ve öğretmenin sorumluluğu altında öğrencilerin değerlerini, tutum ve davranışlarını değiştiren, bilgi ve becerilerini geliştiren içeriği ve süreci yani öğrencinin okul ortamındaki tüm yaşantılarını kapsar. Posner (1995) ise eğitim programını bir öğrenme alanının hedef ve değerlendirme boyutlarını kapsayacak şekilde tüm öğrenilmesi gereken konuların bir listesi olarak tanımlar. Aslında genel anlamda öğrencilerin öğrenme yaşantılarını düzenleme olarak tanımlanabilen (Demirel, 2013) eğitim programı nasıl tanımlanırsa tanımlansın belli ögeleri içinde barındırmalıdır. Bu ögeler Taba’ya (1962) ve Oliver’a (1977) göre şu şekildedir.

Tablo 1. Taba (1962) ve Oliver'ın (1977) eğitim programı öğeleri

\begin{tabular}{cc}
\hline Taba (1962) & Oliver (1977) \\
\cline { 3 - 3 } Hedefler ve Hedef Davranışlar & Çalışma Programı \\
İçeriğin Seçimi ve Düzenlenmesi & Yaşantı Programı \\
Öğrenme-Öğretme Süreci & Hizmet Programı \\
Değerlendirme & Örtük Program \\
\hline
\end{tabular}

Taba’ya (1962) göre bir eğitim programının temel ögeleri hedefler, içerik, öğrenme-öğretme süreci ve değerlendirmeyken, Oliver'a (1977) göre eğitim programının ögeleri çalışma programı, yaşantı programı, hizmet programı ve örtük programdır.

Türkiye'nin yetiştirdiği önemli program geliştirme uzmanlarından olan Varış’a (1994, s. 18) göre ise eğitim programı bir eğitim kurumunun çocuklar, gençler ve yetişkinler için sağladığı, milli eğitim ve kurumun amaçlarının gerçekleştirilmesine dönük tüm faaliyetleri kapsar. Eğitim programı yerine yetişek ifadesini kullanan Ertürk'e (2013) göre ise yetişek geçerli öğrenme yaşantıları düzenidir ve yetişek öğrenci açısından bakıldığında bir öğrenme yaşantıları düzeniyken eğitimci açısından bakıldığında bir eğitim durumları düzenidir. Doğan (1975) ise eğitim programını, hedeflenen davranışları öğrenciye kazandırabilmek için planlanmış faaliyetlerin tümü olarak tanımlar. Demirel'e (2013) göre ise eğitim programı, okulda veya okul dışında planlanmış etkinlikler yoluyla öğrenen sağlanmış öğrenme yaşantıları düzeneğidir. Yukarıda farklı eğitimciler ve program geliştirme uzmanları tarafından yapılan tanımları verilen eğitim programı üstlendikleri görev veya işlevlerine göre farklı gruplara ayrılmıştır. Posner ve Eisner'ın eğitim programına ilişkin gruplandırmaları Tablo 2'de verilmiştir. 
Tablo 2. Posner (1995) ve Eisner'1n (1985) eğitim programları sınıflaması

\begin{tabular}{cc}
\hline Posner (1995) & Eisner (1985) \\
\hline Resmi Program & Resmi Program \\
Uygulamadaki Program & Örtük Program \\
Örtük Program & Göz Ardı Edilen Program \\
Göz Ardı Edilen Program & \\
Destekleyici Program & \\
\hline
\end{tabular}

Resmi program, programa ait tüm ögeleri içinde barındıran yazılı program olarak tanımlanabilir. Uygulamadaki program ise öğretmenin sınıf içinde öğrettiği içeriği, bu içeriğin nasıl öğretildiğini ve öğrencilerin öğrenme çıktılarını kapsar. Örtük program, resmi programda yer almamasına rağmen öğrencilerin davranışlarında değişiklik meydana getiren program anlamına gelmektedir. Göz ardı edilen program ise resmi ya da uygulamadaki programa dahil edilmeyen dersleri, öğretilmeyen konuları ve bunların dahil edilmeme ya da öğretilmeme sebeplerini içeren program anlamına gelmektedir. Son olarak destekleyici program ise resmi program dışında öğrencilerin ilgi alanlarına göre planlanmış öğrenme yaşantılarını destekleyen program anlamına gelmektedir (Demirel, 2013).

Posner'ın (1995) ve Eisner'ın (1985) sinıflandırmalarında yer alan program türlerinin hemen hemen hepsi eğitim alan yazınında kendine yer bulmuş olmasına rağmen, göz ardı edilen program çok fazla tartışmaya konu olmamıştır. Özellikle ulusal alan yazında diğer program türleri hakkında çok fazla çalışma olmasına rağmen, göz ardı edilen program hakkında herhangi bir tez, makale ya da bildiriye rastlanmamıştır. Ancak okullar öğrettikleri kadar öğretmedikleri şeylerden de sorumludurlar (Eisner, 1985) ve göz ard1 edilen programın önemini kavramak eğitim sisteminin, materyallerinin ve içeriğinin planlanmasına yardımcı olmaktadır (Assemi \& Sheikhzade, 2013). Dolayısıyla bu çalışmada, ileride yapılacak başka çalışmalara temel oluşturması amacıyla, eğitimin planlanmasında önemli bir role sahip olan göz ardı edilen programın temel sorular çerçevesinde ayrıntılı bir şekilde tartış1ması amaçlanmıştır. Bu sorular şu şekildedir;

1. Göz ardı edilen program nedir ve temel özellikleri nelerdir?

2. Göz ardı edilen programın program geliştirme sürecinde sağladığı avantajlar nelerdir?

3. Göz ardı edilen programın türleri nelerdir ve bu türlerin Türkiye'deki programlara yansımaları nasıldır?

\section{Göz Ardı Edilen Program ve Temel Özellikleri}

Göz ardı edilen program kavramı, isteyerek ya da farkında olmadan okulda öğretilmeyen konuları kapsayan program olarak tanımlanabilir. Eisner'a (1985) göre okullar sadece öğrettikleri şeylerden değil aynı zamanda bilinçli olarak göz ard1 ettiği ve öğretmediği şeylerden de sorumludurlar. Çünkü öğrenciler okullarda öğrenmedikleri konuların ya hiç farkına varmazlar ya da bu konuların gerçek hayatta ya da okul yaşamlarında önemli olmadığ fikrine kapılırlar. Dolayısıyla, göz ardı edilen program, görmezden gelinen ve anlatılmayan şeylere yönelinmesini ve programın kavramsal olarak nasıl tasarlandığına ve uygulandığına odaklanılmasına vurgu yapar (Gholami, Rahimi, Ghahramani, \& Dorri, 2016). Aslında zaman sorunu yüzünden, fiziksel olarak herhangi bir ders hakkındaki bütün konuların okulda öğretilmesinin imkansız olması sebebiyle bazı konuların bilinçli bir şekilde resmi programa dahil edilmemesi kabul edilebilir bir şeydir (Assemi \& Sheikhzade, 2013). Ancak bazı toplumlarda, hangi konuların programda yer aldığı ya da yer almadığı, nasıl bir öğrenci tipi yetiştirilmek istenmesiyle doğrudan bağlantılı olabilir. Çünkü okulda öğretilen konular bir geleneğin parçasıdır ve gelenekler beklentileri, beklentiler öngörülebilirliği ve o da sürekliliği doğurur (Eisner, 1985). Yani okulda öğretilen her şey, öğrencinin kişiliğinin oluşmasında doğrudan ya da dolaylı olarak etkilidir.

Bahsedilen sebep dolayısıyla, program geliştirme uzmanları bazı konuları öğretim programının dışında bırakmak zorunda kalabilirler (Flinders, Noddings, \& Thornton, 1986). Turist olarak gittiğimiz bir şehirde yapılmas1 gereken birçok şey ya da görülmesi gereken birçok yer vardır. Ancak bunların hepsini yapmak için zaman kısıtlıdır ve bazı şeylerin gezi programına dahil edilmesi bazı şeylerin ise çıkarılması gerekmektedir. Aynı bu gezi programında olduğu gibi, program geliştirmeciler de sınırlı okul kaynaklarını ve zamanı eğitim açısından etkili bir şekilde kullanmaya odaklanmalıdırlar. Dolayısıyla öğretim programına her konu dahil edilemez. Aslında bu durum çok bariz 
bir gerçek olmasına ve kolayca anlaşılabilecek bir şey olmasına rağmen, göz ardı edilen program kavramı ele alınması gereken önemli bir konudur. Çünkü göz ardı edilen programın bazı noktaları bizim program hakkındaki görüşlerimizin temelini oluşturmaktadır (Flinders et al., 1986) ve okullarda öğretilmeyen konular da en az öğretilen konular kadar eğitim açısından önemlidir (Eisner, 1985).

Resmi öğretim programına dahil edilmeyen ve göz ardı edilen programın konusu olan içerik bütün bir dersten ufak bir bilgi parçasına kadar geniş bir yelpazede ele alınabilir (Flinders et al., 1986).

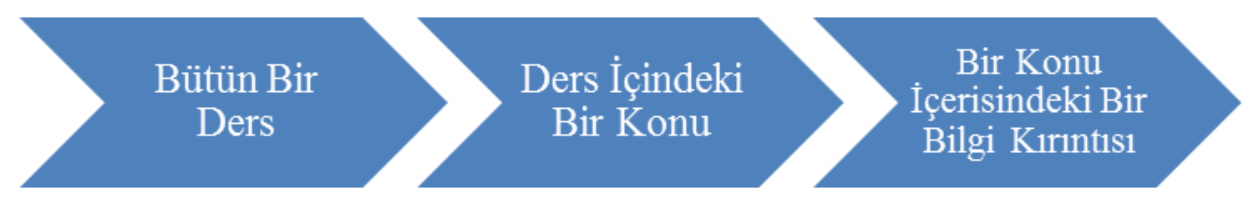

Şekil 1. Resmi öğretim programından göz ardı edilebilecek öğeler

Yani öğretim programından, bütün olarak bir ders çıkartılabileceği gibi, dersin içerisindeki bir konu ya da konunun içerisindeki ufak bilgi parçaları da program içinde göz ardı edilebilir. Örneğin ekonomi, hukuk, psikoloji ve antropoloji gibi dersler birçok ilkokul ve ortaokul programında göz ardı edilme ihtimali yüksek olan derslerdir (Eisner, 1985, p. 103). Bu durum bir dersin bütün olarak öğretim programı içerisinde göz ardı edilmesine örnek olarak verilebilir. Ancak bir dersin içindeki bir konu da göz ardı edilen programa dahil olabilir. Tarih dersleri içerisinde bilim tarihi konusundan hiç bahsedilmemesi ya da biyoloji dersinden evrim konusunun çıkarılması buna örnek olarak verilebilir. Bunlara ek olarak resmi öğretim programına bir ders ya da bir konu dahil edilmiş olsa bile, o konunun bir bölümü anlatılmadan geçiliyor olabilir. Örneğin tarih dersi içerisinde bir olay anlatılırken, o ülke için sadece bu olayın olumlu tarafları derste anlatılabilir ve olumsuz tarafı göz ardı edilebilir (Flinders et al., 1986).

Göz ardı edilen programın önemini kavramak eğitim sisteminin, materyallerinin ve içeriğinin planlanmasına yardımcı olmaktadır (Assemi \& Sheikhzade, 2013). Çünkü ne öğrettiğini bilmek kadar neyi öğretmediğini bilmek de önemlidir. Göz ardı edilen program ancak diğer ülkelerdeki öğretim programları incelenerek belirlenebilir. Sadece var olan programı inceleyerek göz ardı edilen programı tespit etmek imkansızdır (Flinders et al., 1986). Var olan programdaki kazanımlar ayrıntılı bir şekilde sunulmuş olsa bile, evrensel anlamda olması gereken kazanımlar belirlenmeden göz ardı edilen kazanımlar tespit edilemez. Bu sebeple farklı ülkelerin öğretim programlarını inceleyen ve karşılaştıran çalışmalar gerekli ve önemlidir. Bu çalışmalar sonucunda politikacılar, kitap yazarları, öğretmenler ya da öğrenciler tarafından göz ardı edilen konular belirlenebilir ve bu konuların eksikliğinin ileride yol açacağ 1 zararlar önlenebilir. Çünkü kimse anaokulu öğrencilerine ileri matematik öğretilmemesini göz ardı edilen program kapsamında ele alamaz (Flinders et al., 1986). Çünkü hangi ülkeye giderseniz gidin hiçbir anaokulu programında bu konuyu bulamazsınız. Ancak ortaöğretim biyoloji öğretim programında evrim konusunun yer almaması göz ardı edilen program kapsamında ele alınabilir. Dolayısıyla program geliştirme uzmanları ve yöneticiler neyin öğretileceği üzerine zaman harcadıkları kadar, neyin öğretilmeyeceği konusuna da zaman harcamalıdırlar.

\section{Göz Ardı Edilen Program ve Temel Özellikleri}

Göz ardı edilen programın okullardaki yansımalarının çalışılmasının birçok önemli faydası vardır. Bu faydalar şu şekilde gruplandırılabilir.

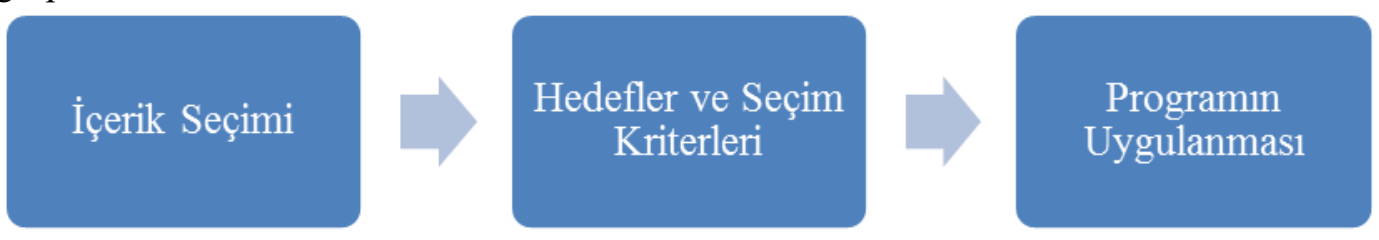

Şekil 2. Göz ardı edilen programın program geliştirme sürecinde sağladığı faydalar

İçerik Seçimi: Göz ardı edilen programın göz önünde bulundurulması, program geliştirme sürecinin içerik seçimi aşamasında farklı alternatiflerin de görülmesini mümkün kılmaktadır. Hangi içeriklerin dahil edileceği ya da hangilerinin göz ardı edileceği konusunda program geliştirme uzmanlarına farklı bakış açıları sunar. Uzmanlar öğretim programının hedeflerini belirledikten sonra iki soru sorabilirler: "Bu hedefler için hangi öğretim programı 
alternatifleri olabilir?" ve "Bu hedefleri gerçekleştirmek için hangi içerik kullanılabilir ve sıralaması nasıl olmalıdır?" $\mathrm{Bu}$ noktada ilk soru program geliştirme uzmanlarının farklı alternatifleri göz önünde bulundurarak, daha geniş bir alanda karar vermesine imkan tanırken ikinci soru uzmanları daha dar bir alana iter ve ihtimalleri azaltır (Eisner, 1985; Flinders et al., 1986).

Hedefler ve Seçim Kriterleri: Göz ardı edilen program belirlenen içerik ışığında, hedeflerin ve seçim kriterlerinin tekrar gözden geçirilmesini teşvik eder. Program geliştirme sürecinin birçok aşamasında içerik, seçim kriteri ve hedefler arasındaki bağa çok fazla odaklanıldığından tutarlı bir program geliştirmek zor bir hal alabilir (Eisner, 1985). $\mathrm{Bu}$ sebeple göz ardı edilen programı ele almak, içerik ve hedefler arasında mantıklı bir ilişki kurmaya yardımcı olur. Örneğin A, B ve C konularını içeren D, E ve F konularını içermeyen bir programı ele alalım. Göz ardı edilen program $\mathrm{D}, \mathrm{E}$ ve $\mathrm{F}$ konularının seçilmeme kriterlerini ve hedeflerle olan ilişkisini incelemeyi gerektirir. Örneğin $\mathrm{D}$ konusu içinde bulunulan çağda artık o ders için önem sahibi bir konu olmayabilir. Böylelikle diğer konuların belirlenmesi için güncel bir şekilde önem sahibi olmak seçim kriteri olarak düşünebilir (Eisner, 1985; Flinders et al., 1986).

Programın Uygulanması: Göz ardı edilen program, resmi öğretim programının uygulanma ihtimallerine kuvvetli bir şekilde odaklanılmasını sağlar. Aynı zamanda, resmi programın uygulanmasındaki firsatları ve kısıtlamaları anlamamıza yardımcı olur. Bu özellik odak noktamızı içerik seçiminden sınıf düzenine, kaynakların durumuna ve okul politikasına çevirmemize neden olmaktadır (Eisner, 1985; Flinders et al., 1986). Örneğin bir okulda fen laboratuvarının olmaması, resmi programdaki deney konularının yapılamamasına neden olabilir. Böylelikle resmi öğretim programında yer almasına rağmen, deney konuları uygulama esnasında göz ardı edilen program kapsamına girebilir.

\section{Göz Ardı Edilen Programın Türleri ve Bu Türlerin Türkiye'deki Programlara Yansımaları}

Alan yazın incelendiğinde, göz ardı edilen programı bilinçli olarak göz ardı edilen, uygulamada göz ardı edilen ve kişisel tecrübeler sonucu göz ardı edilen olmak üzere üç gruba ayıran çalışmaların olduğu görülmektedir (Assemi \& Sheikhzade, 2013). Ancak yukarıda bahsedilen konular ışı̆̆ında göz ardı edilen program, bu çalışmada karar vericiler tarafından göz ardı edilen, müdür ya da öğretmenler tarafından göz ardı edilen ve öğrenciler tarafından göz ardı edilen olmak üzere üç grupta ele alınmıştır.

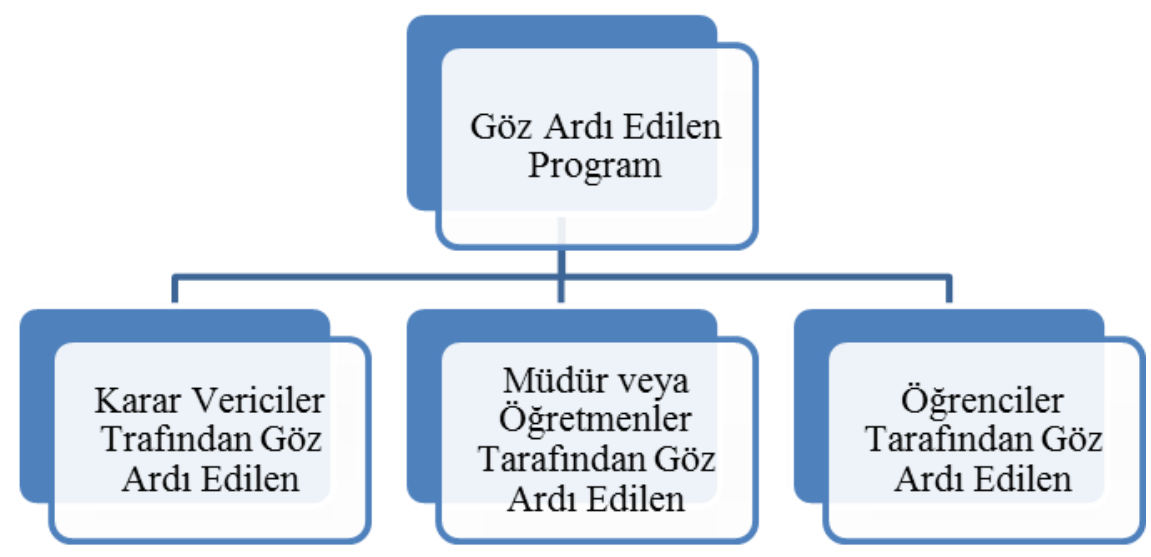

Şekil 3. Göz ardı edilen programın türleri

Karar Vericiler Tarafından Göz Ardı Edilen Program: Bir ülkenin politikacıları, eğitim sistemi hakkında karar vericileri, ders kitabı yazarları ya da yöneticileri tarafından bazı konuların resmi programdan çıkarılması anlamına gelmektedir. Bir eğitim sistemi içindeki konuların belirlenmesinde çevresel faktörler, hükümetler, yöneticiler ve politikacılar etkilidir (Short, 1982). Hükümetler bazı konuların ders kitaplarında yer almasını ya da yer almamasını bilinçli bir şekilde isteyebilirler. Dolayısıyla kitap yazarları bu istekleri göz önünde bulundurmak durumunda kalabilirler (Assemi \& Sheikhzade, 2013). Aynı şekilde, program geliştirme uzmanlarının ilgi alanları ya da 
yetenekleri de programın içeriğinde etkili olabilir. Aslında baskın siyasi iradenin ilgi alanı yönünde hareket etmek zorunda olan program geliştirme uzmanları da bazı konuların programda yer almaması gerektiğine karar verebilirler. Program geliştirme uzmanları ve hükümetlerin yanı sıra, ders kitabı yazarlarının yetenekleri ve özel ilgi alanları da ders kitabının içeriği üzerinde belirleyici olabilir. Korkmaz (2016), 6. sınıf sosyal bilgiler öğretim programını politik bir metin olarak ele aldığı ve öğretim programını, ders ve öğrenci çalışma kitabını ve öğretmen kılavuz kitabını öğretmen ve uzman görüşleriyle incelediği çalışmasında ders materyallerinde neoliberalizmi niteleyen girişimcilik, temel hak ve özgürlükler ve şirket diline yönelik birçok vurgunun olduğu sonucuna ulaşmıştır. Ayrıca milliyetçiliği niteleyen kültürel farklılık ve militarizme ilişkin bulgulara da rastlamıştır. Dolayısıyla araştırma sonucunda elde edilen bulgulara göre ders materyallerinde bazı görüşler bilinçli olarak ön plana çıkarılmakta, bazı görüşler ise göz ardı edilen program kapsamında görmezden gelinmekte ve bu görüşleri niteleyecek konu ve metinler programa hiç dahil edilmemektedir. İnce (2016) ise PISA sınavında yoklanan okuma becerileri açısından 6, 7 ve 8. sınıf Türkçe öğretim programını değerlendirdiği çalışmasında, programda yer alan okuma becerileri kazanımlarının PISA'nın çoğunlukla birinci, ikinci ve üçüncü düzey okuma becerileri yeterlilikleri ile örtüştüğü, beşinci ve altıncı düzey yeterliliklerle ile ise çok az düzeyde örtüştüğü sonucuna ulaşmıştır. Dolayısıyla Türkiye'nin de dahil olduğu birçok OECD ülkesinin girdiği uluslararası bir sınav olan PISA'nın üst düzey yeterlilikleri Türkiye'deki Türkçe öğretim programının kazanımları arasında bile yer almamaktadır. İlk üç düzeye ait kazanımlar ve dolayısıyla içerik programda yer alırken üst düzey beceri yeterlilikleri düzeyine ilişkin kazanımlar ve içerikler program geliştirme uzmanları tarafından göz ardı edilen programa dahil edilmiş durumdadır. Zevfi (2015), ortaokul Türkçe ders kitaplarını öğretim programında yer alan temel beceriler açısından incelediği çalışmasında, ders kitaplarında eleştirel düşünme becerisinin ön plana çıkarıldığı, bilgi teknolojilerini kullanma becerisine ise çok az yer verildiği sonucuna ulaşmıştır. Bu durum da programda yer almasına rağmen kitap yazarları tarafından kendi ilgilerine ya da dönemin şartlarına göre bazı konu ve becerilerin ön plana çıkarılırken bazılarının göz ardı edilmesine örnek olarak verilebilir. Ortaöğretim dokuzuncu sınıf matematik kitaplarının öğretim programına uygunluğunu araştıran Akkaya'ya (2016) göre, ders kitaplarında bazı kazanım ve açıklamaların dikkate alınmamakta ve öğretim programında belirlenen bazı sembol ve terimlere yer verilmemektedir. Dolayısıyla bu durum da, öğretim programında yer almasına rağmen ders kitabı yazarları tarafindan bazı konu ve kazanımların görmezden gelinmesine ve göz ardı edilmesine örnek olarak gösterilebilir. Süzer (2017), Fizik lise öğretim programını ve ders kitabını Almanya ve İngiltere örnekleriyle karşılaştırdığı çalışmasında, Türkiye'deki 11. sınıf fizik programlarında elektrik ve manyetizma ünitesine $\% 50$ oranında bir pay ayrıldığını, aynı üniteye Almanya ve İngiltere'de ayrılan payın \%30 olduğunu belirtmektedir. Bu ünitenin ağırlığı diğer ülkelerden fazladır ve bu fazlalık diğer ünitelerin ağırlığının düşürülmesine sebep olmuştur (Süzer, 2017). Dolayısıyla Türkiye'de diğer Avrupa ülkelerinden farklı şekilde program geliştirme uzmanları tarafından elektrik ve manyetizma ünitesi ön plana çıkarılmış ve diğer bazı üniteler göz ardı edilmiştir. Ayrıca, Süzer'e (2017) göre diğer Avrupa ülkelerinde böyle bir sınırlama olmamasına rağmen, Türkiye'deki 9. ve 10. sınıf fizik öğretim programlarındaki kazanımların bir kısmında, matematiksel işlemlere girilmemesi yönünde sınırlamaya gidilmiştir. Aynı çalışmada elde edilen öğretmen görüşleri de fizik dersinin fazla sözel nitelikte olduğu yönündedir. Dolayısıyla karar vericiler tarafından 9. ve 10. sınıflarda matematiksel işlemlerin görmezden gelindiği ve göz ardı edilen programa dahil edildiğini söylemek mümkündür. Yüzbaşığlu ve Atav (2004) ise ortaöğretim kurumlarında biyoloji öğrenimi görmüş öğrencilerin, biyoloji bilgilerini günlük yaşamda uygulayabilme durumlarını araştırdığı çalışmasında biyoloji öğretim programının günlük yaşam ile ilgili konular açısından yetersiz olduğu ve günlük yaşamla alakası olmayan kuramsal bilgilerin çok fazla olduğu sonucuna ulaşmıştır. Diğer ülkelerde bu durumun böyle olmadığını belirten Yüzbaşığlu ve Atav'a (2004) göre günlük yaşamla ilgili konuların ağırlığının arttırılması gerekmektedir. Yüzbaşığlu ve Atav'ın (2004) çalışmasının bu sonucu da karar vericiler tarafından göz ardı edilen program türüne örnek olarak verilebilir. Üniversitelerin biyoloji öğretmeni yetiştiren bölümlerinin öğretim programlarını inceleyen Işı ve Soran (2005), bazı bölümlerin öğretim programlarında Biyoteknoloji, Embriyoloji, Etoloji, Evrim gibi konular yer alırken, bazılarınınkinde yer almadığını belirtmektedir. Bu durum da karar vericiler tarafından göz ardı edilen programa güzel bir örnek olarak verilebilir.

Müdür veya Öğretmenler Tarafından Göz Ardı Edilen Program: Okul yöneticileri ya da öğretmenler tarafından öğrencilerin ilgisini çekmeyeceği ya da onların işine yaramayacağı düşüncesiyle resmi programdaki ya da ders kitabındaki bazı konuların göz ardı edilmesi anlamına gelmektedir (Assemi \& Sheikhzade, 2013). Örneğin 
üniversiteye giriş sınavına hazırlanan ortaöğretim son sınıf öğrencileri için müzik, resim, beden eğitimi gibi dersler öğretmenler tarafından göz ardı edilerek sınav için önemli olan derslere ağırlık verilebilmektedir. Yani bu dersler öğretim programında yer almasına rağmen okul yönetimi ve öğretmenler tarafından sınava hazırlık süresince öğrencilerin işine yaramayacağı gerekçesiyle göz ardı edilebilmektedir. Cesur (2012) ortaöğretim müzik dersi öğretim programının, okul yöneticilerinin ve velilerin dersi çok fazla önemsemeyen yaklaşımları sebebiyle tamamen uygulanamadığı ve bir kısmının görmezden gelindiğini belirtmektedir. Türkoğlu (2016) ise, ortaokul beden eğitimi ve spor dersi öğretim programını dersi uygulayan öğretmenlerin görüşleriyle incelemeyi amaçladığı çalışmasının sonuçlarına göre, öğretmenler çeşitli alanlarda oluşturdukları okul takımlarına büyük önem ve öncelik vermekte, bu dersi öğrencilerin deşarj olmalarını sağlayan bir aktivite dersi olarak görmekte ve programın içeriğini görmezden gelerek, farklı konulara odaklanmaktadırlar. Dolayısıyla, öğretmenlerin programı uygulama biçimleri öğretim programının amaçlarıyla ve içeriğiyle farklılık göstermektedir. Sonuç olarak bu iki durum öğretmen ya da yöneticiler tarafından uygulamada göz ardı edilen programa örnek olarak gösterilebilir. Ayrıca öğretim programında yer almasına rağmen, öğrenme ortamındaki fiziksel yetersizlikler sebebiyle uygulama aşamasında görmezden gelinmesi zorunlu olan konular olabilir. Örneğin uygun laboratuvar altyapısına sahip olmayan bir okulda, kimya ya da fizik dersi öğretim programında yer alan deney konularının mecburen görmezden gelinmesi öğretmenler tarafından uygulamada göz ardı edilen programa örnek verilebilir. Güven (2016) ile Aybek ve Aslan (2015) fen bilgisi dersi öğretim programı hakkında yaptıkları çalışmalarında, ortak bir şekilde okullarda laboratuvar olmamasının bir sorun olduğunu ve bu sebeple bazı etkinliklerin atlanmak zorunda kalındığını belirtmektedir. Ortaokul müzik derslerinde kullanılan okul çalgılarının, müzik dersi öğretim programını gerçekleştirmedeki yeterliliğini araştıran Karataş ve Kılıç (2017), okulda bulunan çalgıların öğretim programını tamamıyla uygulama konusunda yetersiz kaldığını, blok flüt dışındaki çalgıların öğrenciler tarafından edinilmesinin zor olduğunu ve dolayısıyla da blok flüt dışındaki çalgıların göz ardı edildiğini belirtmektedir. Bunun dışında alan yazında araç gereç eksikliğinden dolayı müzik derslerinde (Aksu, 2007; Cesur, 2012; Köroğlu, 2013; Öztürk, 2006), İngilizce derslerinde (Atabey, 2015), görsel sanatlar derslerinde (Canikoğlu, 2016), İnkılap tarihi ve Atatürkçülük derslerinde (Bayram, 2016), biyoloji derslerinde (Akaydın \& Soran, 1998, Kaya \& Gürbüz, 2002; Uluçınar, Cansaran, \& Karaca, 2004) birçok konu ve etkinliğin göz ardı edilmek zorunda kaldığı sonucuna ulaşan birçok çalışma mevcuttur. Dolayısıyla bütün bu çalışmalarda okul veya sınıfın fiziki yapı elverişsizliğinin, donanım ve materyal eksikliğinin etkinliklerin gerçekleştirilmesini olumsuz yönde etkilediği sonucuna varılmıştır. Bahsedilen bütün çalışmaların sonuçları müdür ya da öğretmenler tarafından uygulamada göz ard1 edilen programa örnek olarak gösterilebilir. Aksu'ya göre (2007) ise ilköğretim ilk kademede müzik öğretmeni eksikliğinden dolayı derslere sınıf öğretmenleri girmekte, bu öğretmenler de birçok konuyu görmezden gelmekte ve dolayısıyla da öğrenciler bir sonraki kademeye birçok bilgi eksiğiyle devam etmektedir. Dolayısıyla bu durum da öğretmenler tarafından uygulamada göz ardı edilen programa örnek olarak gösterilebilir. Ayrıca alan yazında İnkılap Tarihi ve Atatürkçülük dersinde öğretim programının çok yoğun olması ve sürenin yetersiz olması sebebiyle, öğretmenlerin uygulamada bazı konuları sınavlarda çıkmayacağı ya da önemsiz olduğu gerekçesiyle hızlı bir şekilde geçtikleri ya da hiç anlatmadıkları sonucuna ulaşan birçok çalışma mevcuttur (Adalar, 2010; Aslan, 2009; Bayram, 2016; Fettahoğlu, 2011). Dolayısıyla bu durum da, bazı konuların öğretim programında yer almasına rağmen uygulamada öğretmenler tarafından göz ardı edilmesine örnek olarak verilebilir.

Öğrenciler Tarafından Göz Ardı Edilen Program: Öğrencilerin bizzat kendileri tarafından, resmi programdaki ya da ders kitabındaki ilgi alanlarına girmeyen ya da beceremeyeceklerini düşündükleri bazı konuların göz ardı edilmesi anlamına gelmektedir (Assemi \& Sheikhzade, 2013). Öğrenciler sıkıldıkları ya da sevmedikleri dersleri umursamaz bir tavırla alabilir ve bu dersleri göz ardı edebilirler. Ya da yukarıda verilen örnekte olduğu gibi üniversite sınavına hazırlık sürecinde, sınavda az soru çıkacağı ya da hiç soru çıkmayacağı düşünülen konular öğrenciler tarafindan önemsenmeyip göz ardı edilebilir. Bu da resmi öğretim programında yer almasına rağmen, bazı konuların göz ardı edilen program kapsamına kaymasına neden olabilir. Müzik öğretmenlerinin müzik dersi ile ilgili sorunlarını araştıran Gürşen (2002), öğrencilerin müzik dersine yönelik tutumlarının düşük olduğu, dersi almak için yeterince istekli olmadıkları ve bunun da programın uygulanmasını güçleştirdiği sonucuna ulaşmıştır. Aynı şekilde Canikoğlu (2016) da öğrencilerin görsel sanatlar derslerini önemsemediğini ve ilgilerinin düşük olduğunu belirtmektedir. Dolayisıyla 
öğrenciler kendi tecrübeleri sonucunda diğer derslere daha fazla önem vermekte ve işlerine yaramayacağ düşüncesiyle müzik ve görsel sanatlar derslerini göz ardı edilen program kapsamına almaktadır. Yaman, Dervişoğlu ve Soran (2004), ortaöğretim öğrencilerinin biyoloji dersine olan ilgilerini araştırdıkları çalışmalarında, deney ve gözlem ile işlenmesi gereken biyoloji dersinin düz anlatım yöntemiyle işlenmesinin öğrencilerin aklında bu dersin ezbere dayalı bir ders olduğu ve bu dersi beceremeyecekleri algısı yaratması sonucunda derse olan ilginin düştüğünü belirtmektedirler. Dolayısıyla dersi beceremeyeceğini düşünen öğrenciler direk olarak dersi göz ardı edilen program kapsamına almakta ve önemsememeye başlamaktadır.

\section{Tartışma, Sonuç ve Öneriler}

Sonuç olarak, isteyerek ya da farkında olmadan okulda öğretilmeyen konuları kapsayan program olarak tanımlanabilecek (Eisner, 1985) göz ardı edilen program kavramı üzerinde çalışılması gereken önemli bir konudur. Okulların ya da öğretmenlerin sadece öğrettikleri şeylerden değil aynı zamanda göz ardı ettikleri ve öğretmedikleri şeylerden de sorumlu oldukları (Eisner, 1985) göz önüne alındığında, göz ardı edilen kısımların neden görmezden gelindiği ya da neden öğretilmediğinin bilinmesi gerekir. İşte göz ardı edilen program, görmezden gelinen ve anlatılmayan şeylere yönelinmesini ve programın kavramsal olarak nasıl tasarlandığına ve uygulandığına odaklanılmasına vurgu yapar (Gholami et al., 2016). Aslında sınırlı okul kaynaklarını ve zamanı eğitim açısından etkili bir şekilde kullanmaya odaklanan program geliştiriciler her şeyi ya da her konuyu programa dahil edemezler ve bazı şeyleri göz ardı etmek zorunda kalabilirler. Ancak bu göz ardı edilen kısımların neden görmezden gelindiğinin çalışılması ve bilinmesi gereklidir. Bu noktada göz ardı edilen program bize yardımcı olmaktadır. Çünkü göz ardı edilen programın bazı noktaları bizim program hakkındaki görüşlerimizin temelini oluşturmaktadır (Flinders et al., 1986) ve okullarda öğretilmeyen konular da en az öğretilen konular kadar eğitim açısından önemlidir (Eisner, 1985).

Resmi öğretim programına dahil edilmeyen ve göz ardı edilen programın konusu olan içerik bütün bir dersten ufak bir bilgi parçasına kadar geniş bir yelpazede ele alınabilir (Flinders et al., 1986). Yani öğretim programından, bütün olarak bir ders çıkartılabileceği gibi, dersin içerisindeki bir konu ya da konunun içerisindeki ufak bilgi parçaları da program içinde göz ardı edilebilir. Eğitim sisteminin, materyallerinin ve içeriğinin planlanmasına yardımcı olan (Assemi \& Sheikhzade, 2013) göz ardı edilen program ancak diğer ülkelerdeki öğretim programları incelenerek belirlenebilir. Çünkü sadece var olan programı inceleyerek göz ardı edilen programı tespit etmek imkansızdır (Flinders et al., 1986) ve var olan programdaki kazanımlar ayrıntılı bir şekilde sunulmuş olsa bile, evrensel anlamda olması gereken kazanımlar belirlenmeden göz ardı edilen kazanımlar tespit edilemez.

Göz ardı edilen programın okullardaki yansımalarının çalışıımasının içerik seçimi, hedefler ve seçim kriterleri ve programın uygulanması noktasında birçok önemli faydası vardır. Göz ardı edilen programın göz önünde bulundurulması, program geliştirme sürecinin içerik seçimi aşamasında farklı alternatiflerin de görülmesini mümkün kılmaktadır. Hedefler konusunda ise göz ardı edilen program belirlenen içerik 1şı̆̆ında, hedeflerin ve seçim kriterlerinin tekrar gözden geçirilmesini teşvik eder. Bir konunun niçin programa dahil edilmediğinin belirlenmesi, programa dahil edilme kriterlerinin gözden geçirilmesine de olanak sağlar. Programın uygulanması konusunda ise programının uygulanma ihtimallerine kuvvetli bir şekilde odaklanılmasını sağlayan göz ardı edilen program resmi programın uygulanmasındaki fırsatları ve kısıtlamaları anlamamıza yardımcı olur. Böylelikle de odak nokta içerik seçiminden sınıf düzenine, kaynakların durumuna ve okul politikasına çevrilir (Eisner, 1985; Flinders et al., 1986).

Alan yazında göz ardı edilen programı bilinçli olarak göz ardı edilen, uygulamada göz ardı edilen ve kişisel tecrübeler sonucu göz ardı edilen olmak üzere üç gruba ayıran çalışmalar (Assemi \& Sheikhzade, 2013) olmasına rağmen bu çalışmada göz ardı edilen program, bu çalışmada karar vericiler tarafından göz ardı edilen, müdür ya da öğretmenler tarafından göz ardı edilen ve öğrenciler tarafından göz ardı edilen olmak üzere üç grupta ele alınmıştır. Karar vericiler tarafından göz ardı edilen program bir ülkenin politikacıları, eğitim sistemi hakkında karar vericileri, ders kitabı yazarları ya da yöneticileri tarafından bazı konuların resmi programdan çıkarılması anlamına gelmektedir. Müdür veya öğretmenler tarafından göz ardı edilen program ise okul yöneticileri ya da öğretmenler tarafindan öğrencilerin ilgisini çekmeyeceği ya da onların işine yaramayacağı düşüncesiyle resmi programdaki ya da ders kitabındaki bazı konuların göz ardı edilmesi anlamına gelmektedir (Assemi \& Sheikhzade, 2013). Öğrenciler tarafından göz ardı edilen program da öğrencilerin bizzat kendileri tarafından, resmi programdaki ya da ders kitabındaki ilgi alanlarına girmeyen ya da beceremeyeceklerini düşündükleri bazı konuların göz ardı edilmesi anlamına gelmektedir (Assemi \& Sheikhzade, 2013). 
Sonuç olarak içerik seçimi, hedefler ve seçim kriterleri ve programın uygulanması aşamasında ve eğitim sisteminin, materyallerinin ve içeriğinin planlanması konusunda faydası açık bir şekilde ortada olan göz ardı edilen programın yeni çalışmalara konu olması, ayrıntılı bir şekilde çalışılması ve Türkiye'de örneklerinin dikkatli bir şekilde ele alınması gereklidir. 


\section{Extended Summary}

\section{Introduction}

Curriculum, which was used to define oval track during the era of Julius Ceaser, is a more abstract term today in education (Demirel, 2013). Curriculum, which can be defined as the path that is followed to acquire intended knowledge, ability and attitude, is divided into different types by Posner (1995) and Eisner (1985). Null curriculum is one of these types. Although there are many studies about other curriculum types, no study about null curriculum are seen in literature in Turkey. However, schools are responsible for not only what they teach but also what they neglect to teach (Eisner, 1985); and understanding the importance of null curriculum can contribute to planning of education, materials and content (Assemi \& Sheikhzade, 2013). So in this study, it is aimed to discuss the null curriculum elaborately, which has important role on planning education, within the frame of 3 questions, written below, to provide a basis for future studies. This study, which provides summary and synthesis of the knowledge about null curriculum that was found, is literature review.

1. What is the null curriculum and what are its key features?

2. What are the advantages provided by null curriculum during curriculum development process?

3. What are the types of null curriculum and their reflections on curriculums in Turkey?

\section{Null Curriculum and its Key Features}

Null curriculum term can be described as the curriculum which includes what is not taught in schools either intentionally or unintentionally (Eisner, 1985). Schools or teachers are responsible for not only what they teach but also what they neglect to teach (Eisner, 1985). Since, students either do not notice the subjects they do not learn in schools or get the idea that these subjects are not important in real life or their school life. So the reasons, which cause to neglect or not to teach these parts, should be found out and understood. Null curriculum points out to the analysis of what is left out or neglected, and concentrates on how the curriculum is designed and implemented (Gholami, Rahimi, Ghahramani, \& Dorri, 2016). Actually, it is understandable that some of the topics are intentionally excluded from the formal curriculum; because it is impossible to teach all the topics in a subject due to the limited time (Assemi \& Sheikhzade, 2013). However, whether some of the topics are included or not in the formal curriculum can be directly connected to the idea of intended student profile in some societies. The content, which are left out from the formal curriculum and included in the null curriculum, can be anything from the whole lesson to little information (Flinders, Noddings, \& Thornton, 1986).

\section{The Advantages Provided by Null Curriculum during Curriculum Development Process}

Studying the reflections of null curriculum in schools has many benefits for deciding on content, aims and their choosing criteria and implementation of curriculum. Understanding the null curriculum makes possible to see the different alternatives during the decision-making process of the content in curriculum. Null curriculum encourages revising the aims and decision criteria in the light of decided content. It also helps to make meaningful connection between content and aims. Also, null curriculum helps to understand the possible chances and restrictions during the implementation of formal curriculum. So, the focus changes from the decision of content to class organization, situation of the sources and school policy thanks to this advantage of null curriculum (Flinders et al., 1986; Eisner, 1985).

\section{Types of Null Curriculum and Their Reflections on Curriculums in Turkey?}

Although null curriculum is divided into three types as intented, implemented and experiential (Assemi \& Sheikhzade, 2013) in literature, in this study it is discussed in three types as the curriculum which is neglected by decision makers, by headmasters and teachers and by students. Null curriculum, neglected by decision makers, means the exclusion of the some topics from the formal curriculum by politicians, course book writers, administrators or decision makers in education system. Null curriculum, neglected by headmasters and teachers, means the omission of some topics in the formal curriculum or course book, because they think these topics do not attract students' attention or are not important for them (Assemi \& Sheikhzade, 2013). Lastly, null curriculum, neglected by students, means the ignoring 
of some topics, which are not within their area of interest or which are imagined as too difficult to learn, by themselves (Assemi \& Sheikhzade, 2013).

\section{Result}

In conclusion, it is important to study null curriculum, which has many clear advantages in content selection, aims and their selection criteria, implementation of curriculum and planning of education system, materials and the content, in detail. It is also important to investigate the examples of null curriculum in Turkey. 


\section{Kaynakça / References}

Adalar, H. (2010). Sosyal bilgiler öğretmenlerinin 8. sinıf T.C. İnkilâp Tarihi ve Atatürkçülük dersi yeni öğretim programına iliş̧kin görüşlerinin değerlendirilmesi (Yayımlanmamış yüksek lisans tezi). Gazi Osman Paşa Üniversitesi, Tokat.

Akaydın, G., \& Soran, H. (1998). Liselerdeki biyoloji öğretmenlerinin derslerini deneyler ile işleyebilme olanakları. Hacettepe Üniversitesi Ĕ̈itim Fakültesi Dergisi, 14, 11-14.

Akkaya, G. (2016). Ortaöğretim dokuzuncu sınıf matematik ders kitaplarının öğretim programına uygunluğu açısından incelenmesi (Yayımlanmamış yüksek lisans tezi). Hacettepe Üniversitesi, Ankara.

Aksu, C. (2007). İlköğretim 8. slnıf müzik programının hedeflerine ulaşma düzeyinin değerlendirilmesi (Yayımlanmamıs doktora tezi). Atatürk Üniversitesi, Erzurum.

Aslan, D. (2009). İlköğretim yedinci sınıf sosyal bilgiler dersi öğretim programının yapılandırmacı yaklaşım bağlamında öğretmen görüşlerine göre değerlendirilmesi (Yayımlanmamış yüksek lisans tezi). Yeditepe Üniversitesi, İstanbul.

Assemi, A., \& Sheikhzade, M. (2013). Intended, implemented and experiential null curriculum. Life Science Journal, 10(1), 8285.

Atabey, E. (2015). Illkokul ikinci sinıf İngilizce dersi ögretim programının uygulamadaki etkililiğinin değerlendirilmesi (Yayımlanmamış yüksek lisans tezi). Dicle Üniversitesi, Diyarbakır.

Aybek, B., \& Aslan, S. (2015). Sınıf öğretmenlerinin ilkokul 3. sınıf fen bilimleri dersi öğretim programına yönelik görüşlerinin değerlendirilmesi. Uluslarlararast Sosyal Araştırmalar Dergisi, 8(41), 883-894.

Bayram, K. (2016). Sosyal bilgiler öğretmenlerinin ortaokul 8. sınıf T.C. İnkılap Tarihi ve Atatürkçülük dersi öğretim programina iliş̧kin görüşlerinin değerlendirilmesi (Yayımlanmamış yüksek lisans tezi). Ağrı İbrahim Çeçen Üniversitesi, Ağrı.

Canikoğlu, G. (2016). Görsel sanatlar dersi öğretim programındaki "Görsel iletişim biçimlendirme” ögrenme alanının uygulanmasında ortaokul resim öğretmenlerinin görüşleri (Yayımlanmamış yüksek lisans tezi). Gazi Üniversitesi, Ankara.

Caswell, H. L., \& Campbell, D. (1935). Curriculum development. New York, NY: American Book Company.

Cesur, D. (2012). Ortä̈ğretim müzik dersinin işlevselliği (Yayımlanmamış yüksek lisans tezi). Ondokuz Mayıs Üniversitesi, Samsun.

Demirel, Ö. (2013). Eğitimde program geliştirme. Ankara: Pegem Akademi Yayıncılık.

Ertürk, S. (2013). Ĕgitimde program geliştirme. Ankara: Edge Akademi.

Fettahoğlu, B. (2011). 7. sınıf sosyal bilgiler öğretim programının öğretmen görüşlerine göre değerlendirilmesi: Gümüşhane ili örneği (Yayımlanmamış yüksek lisans tezi). Erzincan Üniversitesi, Erzincan.

Doğan, H. (1975). Program geliştirmede sistem yaklaşımı. Ankara Üniversitesi Eğitim Fakültesi Dergisi, 7(14), 361-385.

Doll, R. C. (1986). Curriculum improvement: Decision making and process. Boston, MA: Allyn and Bacon.

Eisner, E. W. (1985). The educational imagination: On the design and evaluation of school programs. New York, NY: Macmillan Publishing Co.

Flinders, D. J., Noddings, N., \& Thornton, S. J. (1986). The null curriculum: Its theoretical basis and practical implications. Curriculum Inquiry, 16(1), 33-42.

Gholami, M., Rahimi, A., Ghahramani, O., \& Dorri, E. R. (2016). A reflection on null curriculum. A Journal of Multidisciplinary Science and Technology, 7(1), 218-223.

Good, C. (1973). Dictionay of education. New York, NY: Mc Graw-Hill.

Gürşen, S. (2002). Milli Eğitim Bakanlığına bağll ilköğretim ve ortaöğretim kurumlarında görev yapmakta olan müzik ögretmenlerinin müzik dersi ile ilgili karşılaş̧tklart sorunlar (Yayımlanmamış yüksek lisans tezi). Marmara Üniversitesi, İstanbul. 
Güven, G. (2016). 3. sınıffen bilimleri dersi ögrretim programına ilişkin ögrretmen görüşleri (Yayımlanmamış yüksek lisans tezi). Mustafa Kemal Üniversitesi, Hatay.

Işık, S., \& Soran, H. (2005). Biyoloji öğretmeni yetiştiren kurumların öğretim programlarının karşılaştırılması. Hacettepe Üniversitesi Eğitim Fakültesi Dergisi, 28, 109-117.

İnce, M. (2016). Türkçe 6, 7, 8. sınıf ögretim programının uluslararası öğrenci değerlendirme programı'nda (PISA) yoklanan "okuma becerileri" açısından analizi: Zonguldak örneği (Yayımlanmamış doktora tezi). Ankara Üniversitesi, Ankara.

Karataş, Y., \& Kılıç, I. (2017). Ortaöğretim düzeyi müzik derslerinde kullanılan okul çalgıları ve bu çalgıların öğretiminde karşılaşılan sorunların incelenmesi. Adlyaman Üniversitesi Sosyal Bilimler Enstitüsü Dergisi, 9(26), 565-601.

Kaya, E., \& Gürbüz, H. (2002). Lise ve meslek lisesi öğrencilerinin biyoloji öğretiminin sorunlarına ilişkin görüşleri. Erzincan Eğitim Fakültesi Dergisi, 4(2), 11-21.

Köroğlu, G. N. (2013). Illköğretim ikinci kademede görev yapan müzik dersi ögretmenlerinin 2006 müzik dersi öğretim programı ile ilgili görüşleri ve karşılaştıkları sorunlar (Yayımlanmamış yüksek lisans tezi). Akdeniz Üniversitesi, Antalya.

Neagley, R. L., \& Evans, D. N. (1967). Handbook for affective curriculum development. New Jersey, NJ: Englewood Clifs, Pentice-Hall Inc.

Olivia, P. F. (1988). Developing the curriculum. Boston, MA: Scott, Foresman and Company.

Oliver, A. I. (1977). Curriculum improvement: A guide to problems, principles and process. NewYork, NY: Harper-Row.

Öztürk, E. (2006). İlköğretim okullarındaki ikinci kademe müzik eğitimi ve sorunları (Yayımlanmamış yüksek lisans tezi). Afyon Kocatepe Üniversitesi, Afyonkarahisar.

Posner, G. J. (1995). Analyzing the curriculum. New York, NY: McGraw-Hill, Inc.

Saylor, J. G., Alexander, W. M., \& Lewis, A. J. (1981). Curriculum planning for better teaching and learning. New York, NY: Holt, Rinehart, \& Winston.

Short, E. C. (1982). Curriculum development and organization. In H. E. Mitzel (Ed.), Encyclopedia of educational research (pp. 405-412). New York, NY: The Free Press.

Süzer, M. A. (2017). Fizik lise ögrretim programının ve ders kitaplarının Almanya ve İngiltere örnekleriyle karşılaştırılması ve ögretmen görüşleriyle değerlendirilmesi (Yayımlanmamış yüksek lisans tezi). Necmettin Erbakan Üniversitesi, Konya.

Taba, H. (1962). Curriculum development: Theory and practice. New York, NY: Har Court, Brace and World.

Tanner, D., \& Tanner, L. N. (1980). Curriculum development: Theory into practice. New York, NY: Mac Millan.

Türkoğlu, Ç. (2016). Beden eğitimi ve spor öğretmenlerinin ortaokul beden ĕgitimi ve spor dersi ögretim programı hakkındaki farkındalık durumlarının incelenmesi (Yayımlanmamış doktora tezi). Gazi Üniversitesi, Ankara.

Tyler, R. W. (1986). Basic principles of curriculum and instructions. Chicago, IL: The University of Chicago Press.

Uluçınar, Ş., Cansaran, A., \& Karaca, A. (2004). Fen bilimleri laboratuvar uygulamalarının değerlendirilmesi. Türk Eğitim Bilimleri Dergisi, 2(4), 465- 475.

Varış, F. (1994). Eğitimde program geliştirme: Teori ve teknikler. Ankara: Alkım Yayıncılık.

Yaman, M., Dervişoğlu, S., \& Soran, H. (2004). Orta öğretim öğrencilerinin derslere ilgilerinin belirlenmesi. Hacettepe Üniversitesi Eğitim Fakültesi Dergisi, 27, 232-240.

Yüzbaşığlu, A., \& Atav, E. (2004). Öğrencilerin günlük yaşamla ilgili biyoloji konularını öğrenme düzeylerinin belirlenmesi. Hacettepe Üniversitesi Ĕ̈itim Fakültesi Dergisi, 27, 276-285.

Zevfi, R. (2015). Ortaokul Türkçe ders kitaplarının Türkçe dersi öğretim programında yer alan temel beceriler açısından incelenmesi (Yayımlanmamış yüksek lisans tezi). Mustafa Kemal Üniversitesi, Hatay. 